Available online at GSC Online Press Directory

GSC Biological and Pharmaceutical Sciences

e-ISSN: 2581-3250, CODEN (USA): GBPSC2

Journal homepage: https://www.gsconlinepress.com/journals/gscbps

(RESEARCH ARTICLE)

\title{
Evaluation of the uses of Eucalyptus species in Makurdi Local Government Area of Benue State, Nigeria
}

\author{
Ekhuemelo David*, Onah Gabriel and Wuam Luther \\ Department of Forest Production and Products, University of Agriculture Makurdi, Benue State, Nigeria.
}

Publication history: Received on 05 September 2017; revised on 02 October 2017; accepted on 09 October 2017

https://doi.org/10.30574/gscbps.2017.1.1.0012

\begin{abstract}
The study was aimed at assessing uses of Eucalyptus species in Makurdi metropolis, Benue State, Nigeria. Snowball sampling technique was employed to select places where Eucalyptus trees were planted in Makurdi. Consequently, five out of these locations were randomly chosen. Target population for this study includes locations where Eucalyptus species were planted, Timber Sheds and stakeholders of forestry in Makurdi. Sum of sixty copies of semi structured questionnaire and personal interview were used for data collection. Results of this present study showed that $72 \%$ of respondents were male while 28\% were female. Three species of Eucalyptus such as Eucalyptus camaldulensis (75\%), Eucalyptus globulus (15\%) and Eucalyptus toreliana (10\%) were identified in the study area. The results revealed that Eucalyptus species were mostly used for windbreak (28.40\%) followed by firewood (26.70\%), aesthetics purpose (21.70\%), landscaping (16.70\%), electric poles $(6.70 \%)$ and $0 \%$ for timber and furniture, respectively. Leave and bark of Eucalyptus species were reported to be used for medicinal purposes with E. camaldulensis most utilized. It was also observed that the stakeholders of forestry in Makurdi had neither Eucalyptus nursery nor plantation. Based on the findings, it is recommended that forestry stakeholders and government should embark sensitization of timber users to initiate Eucalyptus plantation to supplement the ever increasing demand of wood and wood products in Makurdi. Also, timber dealers should explore the Eucalyptus species for timber purposes and business.
\end{abstract}

Keywords: Eucalyptus; Forestry stakeholders; Timber; Medicinal; Aesthetic; Landscaping

\section{Introduction}

There is rapid consumption of wood for construction and furniture in northern Nigeria which is growing day by the day [1]. Constantly increasing population and the corresponding increase in demand for wood and wood based products has heightened wood consumption in Nigeria. As a result of this, the common timber species are getting depleted. Consequently, wood supply is obviously declining and its price becoming increasingly costly. Above all, the rates of growth of the indigenous savanna tree species are generally low and hence cannot meet the ever increasing demand of the people for wood and products [2].

With the help of considerable vegetation by various State forestry establishments across the savanna zones, very low productive forests have since been converted into productive plantation of fast growing exotics such as Pinus spp., Eucalyptus spp., Tectona grandis, Gmelina arborea, Acacia spp., Azadirachta indica etc [1, 3]. The declining availability of the most important economic species in timber market has commenced the exploration of lesser-used species [4]. Oluwadare and Egbewole carried out a study on the quality of Sterculia setigera wood species to ascertain its suitability pulp and paper production. This suggests the need to explore wood species other than the native ones with a view to finding an alternative supply [5].

\footnotetext{
*Corresponding author

E-mail address: davidekhuemelo@ gmail.com
}

Copyright (C) 2017 Author(s) retain the copyright of this article. This article is published under the terms of the Creative Commons Attribution Liscense 4.0. 
It is probing on trend of events that this study seeks to explore the utilization potentials of Eucalyptus species, an indigenized exotic species whose drought tolerance and adaptability have made it particularly suitable for the semiarid regions. Eucalyptus species (family-Myrtaceae) are known for rapid growth. Some of the species in their natural habitat attain very large sizes and are among the tallest trees in the world.

Eucalyptus species are local to Australia yet become broadly worldwide as short turn hardwoods for a range of products and as ornamentals. They have been fruitful as exotics due to their ability for fast growth and tolerance of harsh environments involving many effective adaptations which include indeterminate growth, coppicing, lignotubers, fire, soil acidity, low fertility, drought and insect resistance [6]. According to FAO estimates, Eucalyptus species are highly valuable and extensively planted hardwood in the world [7]. Eucalypts species are grown mostly as exotic plantation species in tropical and subtropical regions throughout Africa, South America, Asia and Australia and, in more temperate regions of Europe, Australia, South and North America.

Eucalyptus species grows very fast and rotate per five years. About $80 \%$ of the total Eucalypts plantation worldwide was occupied by four species and their hybrids from this subgenus namely E. grandis, E. urophylla, E. camaldulensis and E. globules [6]. Some authors reported that Eucalyptus species were raised in the practice of community forestry so as to meet up with timber supply as a result of rise in demand. However, this situation has changed because of its promising economic benefits to the land users [8-9]. Kebebew reported that growing of Eucalyptus species increased the annual income of rural farmers [10]. In addition, Eucalyptus species are utilized globally for a large array of product including essential oil, honey, tannin, pulp for high quality paper, lumber, plywood, veneer, solid and engineered flooring, fiber board, wood cement, composite, mine props, poles, firewood, charcoal, wind brakes and landscape mulch as well as for shade. It is also useful for phytoremediation [11-16].

In view of the previously mentioned background, it is thought here that if another wood species that are locally accessible are tapped, they could supplement or even replace with the accessible exhausted rainforest species. That could solve some of the problems of wood shortages that are being experienced currently. Therefore, the aim of this study was to assess the potential uses of Eucalyptus species in Makurdi.

\section{Material and methods}

\subsection{Study Area}

The study was carried out within Makurdi metropolis, Benue State. Makurdi as the Benue state capital is one of the LGAs in Benue North senatorial District. Makurdi town is located at Latitudes $7^{\circ} 47^{\prime}$ and $10^{\circ} 00^{\prime} \mathrm{N}$ and longitudes $6^{\circ} 25^{\prime}$ and $8^{\circ} 8^{\prime} \mathrm{E}$ of the equator. It is bounded by Guma LGA to the North, Gwer LGA to the south, Gwer -west LGA to the south-west and Doma LGA of Nasarawa State to the North-west. It is situated in the valley on the bank of River Benue [17].

\subsection{Climate and vegetation of Makurdi LGA}

The climate of Makurdi town is the tropical wet and dry type, Koppens AW classification, with double maxima [18]. The rainy season lasts from April to October with 5 months of dry season (November to march). Annual rainfall in Makurdi town is constantly high with an average annual total of approximately $1173 \mathrm{~mm}$ [19]. Temperature in Makurdi is however, generally high in the year with February and March as the hottest months. The highest and lowest mean monthly temperatures of $31^{\circ} \mathrm{C}$ and $26^{\circ} \mathrm{C}$ occurred in March/April and December [20].

The vegetation of Makurdi is guinea savanna type which has been adversely affected by human activities leading to the clear- cutting of trees cover in many parts of the town. This artificial vegetation has replaced the natural secondary vegetation [21].

\subsection{Population and economic activities of Makurdi people}

Makurdi town is inherited by many tribes with a population of 297, 398 to 157, 295 males and 140, 103 females [22]. These tribes include the Tivs, Igedes, Idomas, Etilos, Jukuns, Housas, Yorubas, Ibos and others. The Tivs are the dominant tribe. Makurdi town is made up people largely engaged in civil service, commercial activities and agrarian peasantry. The town is a built up area with highest concentration of people in High level, Wadata and Northbank. Dense population also exists in some low-lying parts of the town such as Wurukum. 


\subsection{Experimental design}

Three main target groups which include locations where Eucalyptus species are planted, Timber Sheds and Stakeholders of Forestry in Makurdi were used for this study as shown in Table 1. Snowball sampling technique was employed to select places where Eucalyptus trees are planted in Makurdi. Five out the Eucalyptus trees sites were randomly selected. Secondly, four main Timber Sheds were purposively chosen. These timber sheds are shown in Table 1.

\subsection{Data collection technique}

A total of sixty copies of semi structured questionnaire were administered to the chosen target groups in the study area. The questionnaires were administered as showed in table 1. In each of the five Eucalyptus plantation locations selected, two copies of questionnaire were purposely administered to owners and residents of the sites, giving a total of ten questionnaires. In each office of the six Forestry stakeholders, five copies were purposively allocated to Senior Officers. While five copies each were randomly administered to Timber Traders in the four Timber Sheds sampled for the study. These summed up to 20 copies of questionnaire for the Timber Sheds. Personal interview was also used to sample information on Eucalyptus species found in the study area.

Table 1 Administration of semi structural questionnaire to target groups

\begin{tabular}{|c|c|c|c|c|c|}
\hline $\begin{array}{l}\text { Sr. } \\
\text { No. }\end{array}$ & $\begin{array}{l}\text { Target } \\
\text { Groups }\end{array}$ & Selected units of target group & $\begin{array}{c}\text { Sampled } \\
\text { number }\end{array}$ & $\begin{array}{c}\text { No. of } \\
\text { questionnaire } \\
\text { per Location }\end{array}$ & $\begin{array}{c}\text { Total No. of } \\
\text { Questionnaire }\end{array}$ \\
\hline 1 & $\begin{array}{l}\text { Forestry } \\
\text { Stakeholders } \\
\text { in Makurdi }\end{array}$ & $\begin{array}{l}\text { Federal University of Agriculture Makurdi } \\
\text { Federal Ministry of environment Makurdi } \\
\text { Federal Department of Forestry Makurdi } \\
\text { State Ministry of environment Makurdi } \\
\text { State Department of Forestry, Makurdi } \\
\text { Forestry Association of Nigeria, Makurdi }\end{array}$ & 6 & 5 & 30 \\
\hline 2 & $\begin{array}{l}\text { Eucalyptus } \\
\text { location } \\
\text { plantation in } \\
\text { Makurdi }\end{array}$ & $\begin{array}{l}\text { Tilley Gardo secondary School, Northbank } \\
\text { Nigerian Union of Journalist (NUJ), Naka Road } \\
\text { Padopas Harmony Secondary School, High level } \\
\text { Lower Benue } \\
\text { Federal Housing Estate, Northbank }\end{array}$ & 5 & 2 & 10 \\
\hline 3 & $\begin{array}{l}\text { Timber } \\
\text { Sheds in } \\
\text { Makurdi }\end{array}$ & $\begin{array}{l}\text { Old bridge Timber Shed, North bank } \\
\text { New bridge Timber Shed Wurukum } \\
\text { Industrial Layout Timber Shed Naka Road } \\
\text { SRS junction Timber Shed (SRSJTS) }\end{array}$ & 4 & 5 & 20 \\
\hline Total & 3 & 15 & 15 & 60 & 60 \\
\hline
\end{tabular}

\subsection{Data analysis}

Descriptive statistics such as percentage, bar chart and pie chart were used to analyze collected data.

\section{Results}

Data on demographic characteristics of respondents are presented in table 2 . The result shows that $72 \%$ of respondents were male while 28\% were female. Most (35\%) of the respondents were within the ages of 30-39 years while $66.06 \%$ were married with $33 \%$ of them involved timber trade as the occupation. The higher number of respondents was in civil service (55\%) and had tertiary education. 
Table 2 Demographic characteristics of respondents

\begin{tabular}{|c|c|c|}
\hline Variables & Frequency & Percentage (\%) \\
\hline \multicolumn{3}{|l|}{ Sex } \\
\hline Male & 43 & 71.66 \\
\hline Female & 17 & 28.30 \\
\hline Total & 60 & 100.0 \\
\hline \multicolumn{3}{|l|}{ Age } \\
\hline $20-29$ & 18 & 30.00 \\
\hline $30-39$ & 21 & 35.00 \\
\hline $40-49$ & 16 & 26.00 \\
\hline 50 and above & 5 & 8.33 \\
\hline Total & 60 & 100.0 \\
\hline \multicolumn{3}{|l|}{ Marital Status } \\
\hline Single & 18 & 30.00 \\
\hline Married & 40 & 66.06 \\
\hline Divorced & 2 & 3.33 \\
\hline Widow & 0 & 0.00 \\
\hline Total & 60 & 100.0 \\
\hline \multicolumn{3}{|l|}{ Occupation } \\
\hline Civil service & 33 & 55.00 \\
\hline Student & 4 & 6.66 \\
\hline Timber Trading & 20 & 33.33 \\
\hline Trading & 1 & 1.66 \\
\hline Farming & 2 & 3.33 \\
\hline Total & 60 & 100.0 \\
\hline \multicolumn{3}{|l|}{ Education } \\
\hline Informal & 3 & 5.00 \\
\hline Primary & 9 & 15.00 \\
\hline Secondary & 15 & 25.00 \\
\hline Tertiary & 33 & 55.00 \\
\hline Total & 60 & 100.0 \\
\hline
\end{tabular}

Table 3, shows identified Eucalyptus species in Makurdi. This study revealed that E. camaldulensis (75\%) was mostly common followed by E. globulus (15\%) and the least was E. torreliana (10\%).

Table 3 Eucalyptus species found in Makurdi

\begin{tabular}{lllcc}
\hline Sr. No. & Scientific name & Common Name & Frequency & Percentage (\%) \\
\hline 1 & E. camaldulensis & Red gum/River Gum & 45 & 75 \\
2 & E.globulus & Blue Gum & 9 & 15 \\
3 & E. Toreliana & Cadagi Gum & 6 & 10 \\
& Total & & 60 & 100 \\
\hline
\end{tabular}


Table 4, indicates the uses of Eucalyptus species in Makurdi. It was observed that the highest (28\%) use of Eucalyptus species grown in Makurdi was for the purpose of windbreak. This was closely followed by firewood (26.70\%). Aesthetics uses of Eucalyptus species was $21.70 \%$. While its use for landscaping and electric poles purposes were $16.70 \%$ and $6.70 \%$, respectively. There was no record of Eucalyptus species use for timber, furniture/carpentry, plywood and particle board in Makurdi.

Table 4 Uses of Eucalyptus species in Makurdi

\begin{tabular}{clcc}
\hline Sr. No. & Uses & Frequency & Percentage (\%) \\
\hline 1 & Timber & 0 & 0.00 \\
2 & Fire wood & 16 & 26.70 \\
3 & Furniture/carpentry & 0 & 0.00 \\
4 & Plywood/particle board & 0 & 0.00 \\
5 & Electric poles & 4 & 6.70 \\
6 & Landscaping & 10 & 16.70 \\
7 & Aesthetics purpose & 13 & 21.70 \\
8 & Windbreak & 17 & 28.30 \\
& Total & 60 & 100.0 \\
\hline
\end{tabular}

\subsection{Uses of Eucalyptus species on health matters in Makurdi}

Table 5, indicates traditional uses of Eucalyptus species by respondents for medicinal purpose in Makurdi. From the result, 37\% respondents used E. camaldulensis leaves for the treatment of typhoid fever, $27 \%$ used it for treatment of malaria fever and stomach upset, while 25\% used it for cough suppression. Also, 13\% and 10\% used the leaves for ulcer and muscle/joint pains reliever, respectively. E. camaldulensis leaves and bark were noted for the treatment of fungi infection (22\%), blood sugar control (7\%) and treatment of skin diseases (5\%). Whereas $15 \%$ respondents used E. toreliana leaves for wound treatment, $28 \%$ and $8 \%$ used E. globulus leaves for cold reliever and treatment of respiratory ailment, respectively.

Table 5 Traditional uses of Eucalyptus species for medicinal purpose

\begin{tabular}{|c|c|c|c|c|c|}
\hline Sr. No. & Species & Part Used & Uses & Frequency & Percentage (\%) \\
\hline \multirow[t]{10}{*}{1} & E. camaldulensis & Leaves & Use for the treatment of typhoid fever & 22 & 37 \\
\hline & & Leaves & Treatment of malaria fever & 16 & 27 \\
\hline & & Leaves/bark & For the treatment of skin disease & 3 & 5 \\
\hline & & Leaves & Cough suppression & 15 & 25 \\
\hline & & Leaves & Treatment of stomach upset & 16 & 27 \\
\hline & & Leaves & Muscle/joint pain reliever & 6 & 10 \\
\hline & & Leaves/bark & Treatment of fungi infection & 13 & 22 \\
\hline & & Leaves/bark & Blood sugar control & 4 & 7 \\
\hline & & Oil & Hair nourishment & 7 & 12 \\
\hline & & Leaves & Treatment of ulcer & 8 & 13 \\
\hline 2 & E. torreliana & Leaves & Wound treatment & 9 & 15 \\
\hline \multirow[t]{3}{*}{3} & E. globulus & Leaves & As cold reliever & 17 & 28 \\
\hline & & leaves & Treatment of respiratory ailment & 5 & 8 \\
\hline & Total & & & 60 & 100 \\
\hline
\end{tabular}




\subsection{Presence of Eucalyptus plantation and nursery in Makurdi}

Results on establishment of Eucalyptus nursery/plantation in Makurdi is presented in table 6. From the result, 100\% of the respondents did not have Eucalyptus nursery and plantation.

Table 6 Establishment of Eucalyptus nursery/plantation in Makurdi

\begin{tabular}{|c|c|c|c|c|c|}
\hline \multirow{3}{*}{$\begin{array}{l}\text { Sr. } \\
\text { No. }\end{array}$} & \multirow{3}{*}{ Sampled Areas } & \multicolumn{4}{|c|}{ Eucalyptus Nursery/Plantation } \\
\hline & & \multicolumn{2}{|c|}{ Yes } & \multicolumn{2}{|c|}{ No } \\
\hline & & Frequency & $\begin{array}{c}\text { Percentage } \\
\text { (\%) }\end{array}$ & Frequency & $\begin{array}{c}\text { Percentage } \\
(\%)\end{array}$ \\
\hline 1 & Forestry Association of Nigeria, Makurdi & 0 & 0 & 5 & 8.30 \\
\hline 2 & Federal Ministry of Environment, Makurdi & 0 & 0 & 5 & 8.30 \\
\hline 3 & Federal Department of Forestry, Makurdi & 0 & 0 & 5 & 8.30 \\
\hline 4 & Location Eucalyptus were grown & 0 & 0 & 10 & 16.70 \\
\hline 5 & State Ministry of Environment, Makurdi & 0 & 0 & 5 & 8.30 \\
\hline 6 & State Department of Forestry, Makurdi & 0 & 0 & 5 & 8.30 \\
\hline 7 & Timber Shades & 0 & 0 & 20 & 33.30 \\
\hline \multirow[t]{2}{*}{8} & Federal University of Agriculture Makurdi & 0 & 0 & 5 & 8.30 \\
\hline & Total & & & 60 & 100.0 \\
\hline
\end{tabular}

\subsection{Locations where Eucalyptus species were grown in Makurdi}

The information presented in Table 7, shows the three species of Eucalyptus and various locations where they are grown in Makurdi and the reasons why they were grown. In lower Benue, E. camaldulensis were grown for windbreak, aesthetic purpose and landscaping. In Federal University of Agriculture, Makurdi, it was reportedly grown for shade, aesthetic purpose and landscaping. Nigerian Union of Journalist (NUJ) environs raised the species for aesthetic purpose, windbreak and landscaping. Whereas, in Federal Housing at North Bank, Makurdi, E. camaldulensis were said to be grown for aesthetic purpose and shade. In Tilley Gado College, E. camaldulensis were grown mainly for shades, aesthetic purpose and landscaping.

Table 7 Locations where Eucalyptus species are grown in Makurdi

\begin{tabular}{llll}
\hline Sr. No. & Eucalyptus species & Location grown & Reasons for grown \\
\hline 1 & E. camaldulensis & Lower Benue & Windbreak, aesthetic purpose, landscaping \\
& & University of Agriculture & Shades, aesthetic purpose, landscaping \\
& Nigeria Union of Journalist & Aesthetic purpose, windbreak, landscaping \\
& Federal Housing, North Bank & Aesthetic purpose and shade \\
& & Tilley Gado College, North Bank & Shade, aesthetic purpose, landscaping \\
& E.globulus & Federal University of Agriculture & Shade, landscaping and aesthetic purpose \\
& E. toreliana & Federal University of Agriculture & Shade, aesthetic purpose and landscaping \\
\hline
\end{tabular}

Figure 1, shows interest of respondents in massive plantation establishment of Eucalyptus species in Makurdi. According to result, 24\% of Stakeholders supported massive plantation of Eucalyptus species, 11\% Timber Shed owners advocated for massive growth while 6\% from different places where Eucalyptus species were grown also supported the massive plantation of Eucalyptus species in Makurdi. Figure 2, shows Eucalyptus stands planted for 
beautification in Federal University of Agriculture Makurdi. The species were grown for landscaping, shade and aesthetic purposes.

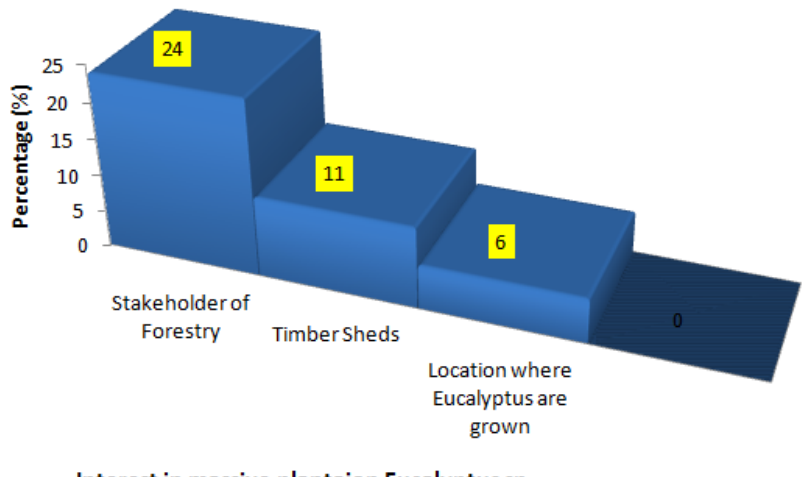

Interest in massive plantaion Eucalyptus sp.

Figure 1 Percentage interest in massive plantation of Eucalyptus species in Makurdi
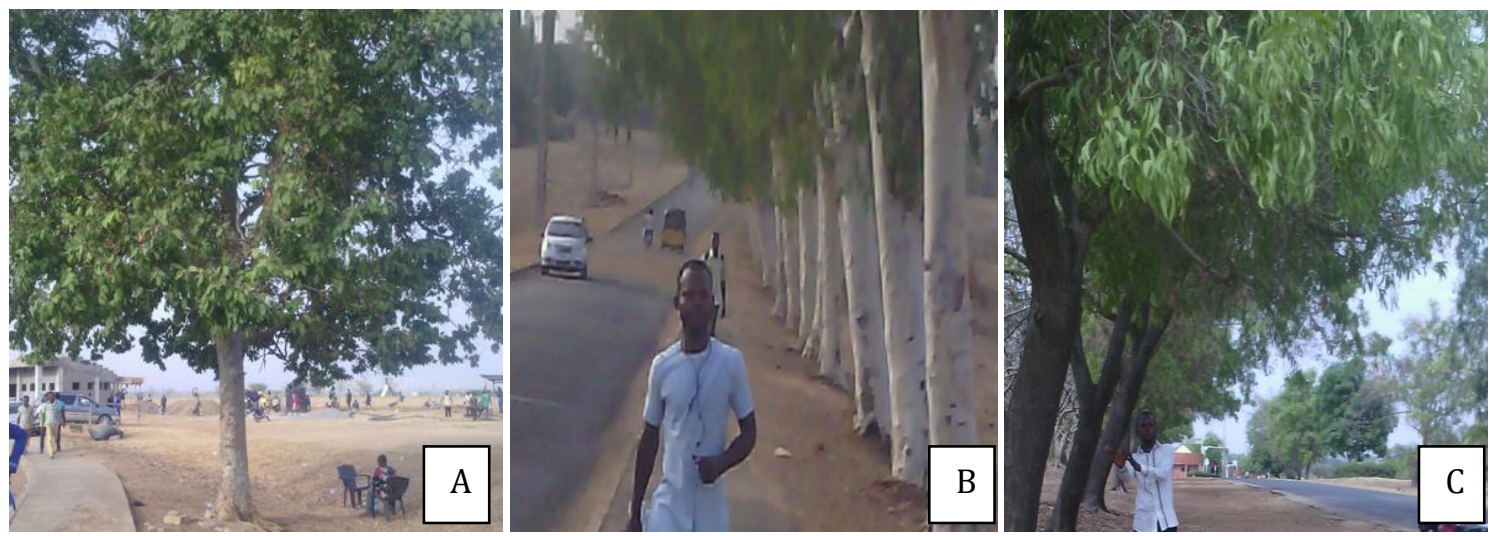

Figure 2 (A) E. toreliana in South Core, FUAM, (B) E. camaldulensis in South Core, FUAM, (C) E. globulus in South Core, FUAM

\section{Discussion}

In this study, the number of male respondents surpassed their female counterparts. The low number of female respondents may be because forestry and wood business require physical strength found more in men than women. This finding is similar to Rongo and Leon and Ekhuemelo et al., who reported that males are dominant in wood working processes [23-24].

The study revealed that E. camaldulensis, E. globulus and E. torreliana were found in Makurdi with E. camaldulensis as the most dominate of the three. This may be because it is the fastest growing and tolerable species among the three species. This confirm the findings of Rockwood et al. who stated that that E. camaldulensis was successful as exotics because of their capacity for fast growth and tolerance of harsh environments involving many effective adaptations which include indeterminate growth, coppicing, lignotubers, , fire, tolerance of soil acidity and low fertility, drought and insect resistance [6].

The study further revealed that Eucalyptus species within Makurdi were used mainly for windbreak firewood, aesthetics purpose and electric poles. There respondents were not aware that they can be used for timber purposes. This finding is at variance with Babatola and Abubarkar, who reported that Eucalyptus species were grown extensively worldwide as short rotation hardwoods for a variety of products and as ornamentals [1]. The rate of wood consumption for construction and for furniture in northern Nigeria is growing by the day. As a result Eucalyptus species should be massively grown in Makurdi to meet the ever increasing demands for wood for construction purposes. It was reported that Eucalyptus species under community forestry was to meet timber supply due to rise in the demand of wood [8-9]. Eucalyptus species are utilized globally for a large array of product including essential oil, honey, tannin, pulp for high quality paper, lumber, plywood, veneer, solid and engineered flooring, fiber board, wood 
cement, composite, mine props, poles, firewood, charcoal, wind brakes and landscape mulch as well as for shade. It is also useful for phytoremediation [11-16].

Babatola and Abubarkar reported that large density values recorded from their research on density and bending strength characteristics of north western Nigerian grown E. camaldulensis in relation to utilization as timber placed the wood at an elevated position of suitability in the wood to compete favorably with some commercially available timber species in Nigeria [1]. They further asserted that the bending strength and modulus of elasticity values compared favorably and even superior to some of the species currently used in Nigeria.

Eucalyptus has been used traditionally for medications and has been used for the treatment of diseases for a very long time [25]. The findings this study reveals that Eucalyptus species were used for the treatment of several diseases such as typhoid fever, ulcer, malarial fever cough, stomach upset, blood sugar skin infection in the study area. This result supports the finding of Adeniyi et al. who reported that essential oils of the leaves of E. camaldulensis were used in the treatment of lung diseases, while the volatile oils were used as expectorants [26]. Ointments from Eucalyptus oil have been reportedly used in customary indigenous medicines to treat injuries and fungal diseases. Eucalyptus oil obtained by steam distillation and rectification of the fresh leaves has Eucalyptol (1,8-cineole) as its active ingredient and this is responsible for its various pharmacological actions [27]. The antimicrobial activities of the methanolic extracts of $E$. camaldulensis have also been reported [28]. The emergence of bacterial resistance to the currently available antimicrobial drugs necessitates further research in the discovery of new safe and effective antibacterial agents [29]. EMA reported that Eucalyptus leaves of E. globulus were often marketed as a combination with other herbal substances/preparations for the treatment of cough associated with cold [30].

The study further reveals that there was no Eucalyptus nursery and plantation in Makurdi except for beautification. This result is at variance with findings of Jacobs who reported that, Eucalyptus has been extensively planted in Australia, Asia, South America, and Africa, with plantations established in the U.S. starting in the mid-1800s [31]. The result is also at variance with Rockwood et al. who claimed that Eucalyptus species was grown extensively worldwide as short rotation hardwoods for a variety of products and as ornamentals [6]. Rockwood et al. further asserted that Eucalyptus species have been flourishing as exotics because of their capacity for fast growth and tolerance of harsh environments involving many effective adaptations [6]. Most respondents advocated support for massive establishment of Eucalyptus species in the area may be as a result of the enlightenment they got in exposure to this study.

\section{Conclusion}

This study revealed three species of Eucalyptus species such as E. camaldulensis, E. gobulus and E. toreliana found in Makurdi. Eucalyptus species found within Makurdi were used for firewood, landscaping, aesthetic and windbreak purposes, while the bark, leaves, oil from seeds and the root were used for medically for treatment of typhoid fever, malarial fever, skin infection, cough, stomach upset, fungi infection, blood sugar, hair nourishment, ulcer, wound, cold and respiratory ailment. Eucalyptus wood was no sold as timber in any Timber Sheds or any parts of Makurdi and also, no Eucalyptus plantations or nursery was established in Makurdi for commercial purposes for timber production because dearth of information on the species. Finally, the level of awareness on the uses of Eucalyptus was very low. Based on the findings of the study, we recommend that Forestry Stakeholders and government should embark on sensitization of timber users. This would help to initiate Eucalyptus plantation establishment to supplement the ever increasing demand of wood and wood products in Makurdi. Timber dealers should explore the Eucalyptus species for timber purposes and business.

\section{Compliance with ethical standards}

\section{Acknowledgments}

The authors wish to thank Forestry Stakeholders, Timber dealers in Makurdi and all individuals who provided useful information for the success of this study.

\section{Disclosure of conflict of interest}

There is no conflict of interest. 


\section{References}

[1] Babatola 0 and Abubarkar M. (2011). Density and bending strength characteristics of North Western Nigerian grown E. camaldulensis in relation to utilization as timber. Research Journal of Forestry, 5, 107-114.

[2] Otegbeye GO. (2004). Drought and desertification: Challenges for afforestation in Nigerian arid and semi-arid regions. Savanna, 19, 1-11.

[3] Momodu AB, Otegbeye GO and Igbuanugo AB. (1997). The priority multipurpose tree species (MPTS) of the arid and semi arid areas of Nigeria: Identification, distribution and ethnobotanic values. Seminar paper delivered at the Forestry Research Institute of Nigeria Conference Hall, Ibadan, on June.

[4] Oluwafemi OA and Adegbenga SO. (2007). Preliminary report on utilization potential of Gliricidia sepium (Jacq.) steud for timber. Research Journal of Forestry, 1, 80-85.

[5] Oluwadare AO and Egbewole ZT. (2008). Wood quality studies in plantation-grown sterculia (Sterculia setigera Del.) in the Guinea Savanna, Nigeria. Research Journal of Forestry, 2, 22-33.

[6] Rockwood DL, Rudie AW, Ralph SA, Zhu JY and Winandy JE. (2008). Energy product options for Eucalyptus species grown as short rotation woody crops. International Journal of Molecular Science, 9, 1361-1378.

[7] FAO (2005). Global forestry resource, assessment. 2005 main reports, FAO forestry paper.

[8] Meknonnen A. (2000). Variation of community forestry in Ethiopia: A contingent valuation study of rural households. Environment and Development Economics, 5, 289-308.

[9] Liu H and Li J. (2010). The study of ecological problems of Eucalyptus plantation and sustainable development in the Maoming Xiaoliang. Journal of sustainable Development, 3, 1997-2001.

[10] Kebebew Z. (2010). Eucalyptus in rural livelihood safety net strategy in coffee growing area: Case study around Jimma, South Western Ethiopia. Research Journal of Forestry, 42, 202-207.

[11] Tournier V, Grat S, Marque C, El-Kayal W and Penchel R. (2003). An efficient procedure to stably introduce genes into an economically important pulp tree (Eucalyptus grandis $\mathrm{x}$ Eucalyptus urophylla). Transgenic Research, 12, 403-411.

[12] Gorrini B, Poblete H, Hernandez G and Dunn, F. (2004). Particle board and MDF using Eucalyptus nitens: Industrial scale experiments. Bosque, 25, 89-97.

[13] Krzysik AM, Muehl JH, Youngquist JA and Franca FS. (2000). Medium density fiberboard made from Eucalyptus saligna. Forest Products Journal, 51, 47-50.

[14] Foley, W. J. and Lassak, E. V. (2004). The potential of bioactive constituents of Eucalyptus foliage as non-wood products from plantations. Rural Industries Research and Development Corporation, Australia.

[15] Coutts RSP. (2005). A review of Australian research into natural fibre cement composites. Cement Concrete Composites, 27, 518-526.

[16] Barton A. (2007). Industrial uses of Eucalyptus oil white paper. (www.oilmallee.com.au/docs/BARTON.doc).

[17] Gyang EO. (1997). Students information handbook (1996-1998). University of Agriculture, Makurdi, 1-3.

[18] Ayoade JO. (1983). Introduction to climatology for the tropics. Chichester: John Wiley and Sons.

[19] Abah RC. (2012). Causes of seasonal foding in flood plains: a case of Makurdi, Northern Nigeria. International Journal of Environmental Studies, 69(6), 904-912.

[20] Tyubee BT. (2010). An assessment of vulnerability to climate change risks in Makurdi, Nigeria. ACCFP Final Technical Report.

[21] Ologunorisa ET and Tor T. (2002). The changing rainfall pattern and its implication for flood frequency in Makurdi, Northern Nigeria. Journal of Applied Science Environmental Management, 10 (3), 97 - 102.

[22] FGN (2007). Details of the breakdown of the national and state provisional population totals of 2006 census. Federal Government of Nigeria Official Gazette, 94(24), 175-198.

[23] Rongo LMB, and Leon B. (2005). Qualitative method for assessing dust exposure in small-scale wood industries in the informal sector. East African Journal of Public Health, 2(1), 32-38. 
[24] Ekhuemelo D0, Iorpenda MA and Tembe ET. (2017). Analysis of wood- based enterprise in Gboko local government area of Benue State, Nigeria. Asian Research Journal of Agriculture, 4(1), 1-10.

[25] Jaswant R, Pankaj G and Bipin KA. (2015). Approach of Eucalyptus globulus plant parts for human health safety and toxicological aspects. British Open Journal of Plant Science 1(1), 1-10.

[26] Adeniyi BA, Lawal TO and Olaleye SB. (2006). Antimicrobial and gastroprotective activities of E. camaldulensis (Myrtaceae) crude extracts. Journal of Biological Sciences, 6(6), 1141-1145.

[27] Trivedi NA and Hotchandani SC. (2004). A study of the antimicrobial activity of the oil of Eucalyptus. Indian Journal of Pharmacology, 36, 93-94.

[28] Akin-Osanaiye BC, Agbaji AS and Dakare MA. (2007). Antimicrobial activity of oils and extracts of Cymbopogon citrates, Eucalyptus citriodora and Eucalyptus camaldulensis. Journal of Medical Sciences, 7(4), 694-697.

[29] Lokhande PD, Gawai KR, Kodam KM, Kuchekar BS, Chabukswar AR and Jagdale SC. (2007). Antibacterial activity of isolated constituents and extract of roots of Inula racemosa. Resource Journal of Medical Plant, 1(1), 7-12.

[30] Europeans Medicines Agency (EMA) (2012). Assessment report on Eucalyptus globulus Labill., folium. EMA/HMPC/892615/2011 Committee on Herbal Medicinal Products (HMPC), 16d (1).

[31] Jacobs MR. (1979). Eucalypts for Planting; FAO Forestry Series No. 11; Food and Agriculture Organization of the United Nations: Rome, Italy, p. 677.

\section{How to cite this article}

Ekhuemelo D, Onah G and Wuam L (2017). Evaluation of the uses of Eucalyptus species in Makurdi Local Government Area of Benue State, Nigeria. GSC Biological and Pharmaceutical Sciences, 1(1), 25-34. 